\title{
Contribution to the knowledge of the distribution of Chaoborus species (Diptera: Chaoboridae) in the NE Iberian Peninsula, with notes on the spatial and temporal segregation among them
}

\author{
Ignasi Arranz ${ }^{1,2, *}$, Jordi Sala ${ }^{1}$, Stéphanie Gascón ${ }^{1}$, Albert Ruhíi ${ }^{1,3}$, Xavier D. Quintana ${ }^{1}$, Joan \\ Amoedo $^{4}$, Mònica Martinoy ${ }^{5}$ and Dani Boix ${ }^{1}$ \\ ${ }^{1}$ GRECO, Institute of Aquatic Ecology, Faculty of Sciences, University of Girona. Av. Maria Aurèlia Capmany, \\ 69, 17071 Girona, Catalonia, Spain. \\ ${ }^{2}$ BETA Technology Centre, Aquatic Ecology Group, University of Vic-Central University of Catalonia, 08500 \\ Vic, Catalonia, Spain. \\ ${ }^{3}$ Global Institute of Sustainability, Arizona State University. Tempe, Arizona 85287, USA. \\ ${ }^{4}$ Carrer Borrassà, 28, $1^{\mathrm{r}}, 17600$ Figueres, Catalonia, Spain. \\ ${ }^{5}$ Carrer Ramon Boy, 19, 17257 Torroella de Montgrí, Catalonia, Spain. \\ * Corresponding author: ignasi.arranz@uvic.cat
}

Received: 24/02/2014

Accepted: 20/11/2014

\begin{abstract}
Contribution to the knowledge of the distribution of Chaoborus species (Diptera: Chaoboridae) in the NE Iberian Peninsula, with notes on the spatial and temporal segregation among them

Phantom midges are characteristic inhabitants of standing waters and are well known for their diel migrations. Despite the extensive body of literature covering their ecology, there are still knowledge gaps with regards to the factors that determine their distribution. Furthermore, although spatial and temporal segregation patterns among chaoborids have long been reported, the prevalence of such patterns in shallow waters remains unclear. We investigated the distribution of Chaoborus species, as well as their spatial and temporal segregation and diel mesohabitat migration, in the NE Iberian Peninsula. We detected three Chaoborus species (C. crystallinus, C. pallidus and C. flavicans), with the latter being the most dominant, and co-occurrences among these species being very low. C. flavicans did not perform diel horizontal migrations, although in one of the ponds it showed high affinities to vegetated areas during both day- and night-time, similar to its potential predators. Therefore, although we did not observe the role of diel horizontal migrations as an antipredator mechanism in shallow water bodies, aquatic vegetation could confer refuge to the chaoborid larvae.
\end{abstract}

Key words: Chaoborus, shallow waterbodies, diel mesohabitat migration, segregation, Iberian Peninsula.

\section{RESUMEN}

Contribución al conocimiento de la distribución de las especies de Chaoborus (Diptera: Chaoboridae) en el NE de la Península Ibérica, con notas sobre la segregación espacial y temporal entre ellas

Las larvas del género Chaoborus son unos habitantes típicos de aguas estancadas con unos patrones muy marcados de migración vertical diaria. Aunque existe una extensa bibliografía de su papel ecológico y biológico, existen aún algunos interrogantes en relación a su distribución. Además, aunque los patrones de segregación espacial y temporal en los caobóridos están bien documentados, en aguas someras siguen sin estar claros. Nuestro estudio se centra en la distribución de las especies del género Chaoborus en el NE de la Península Ibérica, su segregación espacial y temporal y las migraciones diarias entre mesohábitats. Se detectaron tres especies del género Chaoborus (C. crystallinus, C. pallidus y C. flavicans), siendo la última la más abundante, y unas coocurrencias entre estas especies muy bajas. C. flavicans no mostró ninguna migración diaria horizontal, aunque en una de las charcas presentó una afinidad mayor por las zonas vegetadas tanto de día como de noche, al igual que sus predadores potenciales. Por lo que, aunque no se observaron patrones de migración horizontal diaria como mecanismo antipredador en masas de agua someras, la vegetación acuática podría suponer un refugio para las larvas de Chaoborus.

Palabras clave: Chaoborus, aguas someras, migración diaria en el mesohabitat, segregación, Península Ibérica. 


\section{INTRODUCTION}

The Chaoboridae family (commonly known as phantom midges) includes 50 extant species in 6 genera and 2 subfamilies (Wagner et al., 2008). The genus Chaoborus is the most speciated, including 42 species with a worldwide distribution (except Antarctica) (Borkent, 1993; Wagner et al., 2008). Chaoborus larvae are a typical element of standing waters, and in large water bodies, they display a well-known vertical migration to avoid visual predators (i.e., they reside in the bottom during the day as a refuge, and they migrate at night to feed; Sæther, 1972). Although there is a wide knowledge of the biological and ecological roles of the different Chaoborus species, the geographic distribution of some species still has large gaps (Borkent, 1979; Berendonk, 2002). In the case of the Iberian Peninsula the genus is widely distributed (e.g., Carles-Tolrá \& Saloña, 2004; Geraldes \& Boavida, 2004; Abellán et al., 2006; Trigal et al., 2007; Florencio et al., 2009; Alarcón-Elbal et al., 2011; Martínez-Sanz et al., 2012). However, the identity and the exact distribution of the different species, and the factors that determine this distribution, are still not completely known.

Although the actual coexistence of two or more species of Chaoborus in the same water body is not rare (Stahl, 1966), spatial and temporal segregation patterns among chaoborid species have been largely reported (e.g., Von Ende, 1979; Kurek et al., 2010). Different strategies devoted to avoid or reduce interspecific competition have been described, such as adaptation to different environmental characteristics (Lamontagne et al., 1994; Kurek et al., 2010) or to habitats with different predation pressure (Von Ende, 1979; Garcia \& Mittelbach, 2008), intraguild predation (Von Ende, 1979; Persaud \& Dillon, 2010), different capacities of dispersion (Berendonk \& Bonsall, 2002), or different phenologies (Von Ende, 1982).

Diel migrations are behavioural strategies adopted by chaoborids and represent a trade-off between living in resource-rich surface waters with a high predation risk and living in resource- poor deep waters with a low predation risk. These diel migrations have been generally considered a response to fish presence (e.g., Dawidowicz et al., 1990; Tjossem, 1990) but they have also been observed in temporary pools (Bass \& Sweet, 1984). Within this context, diel patterns of Chaoborus species have been studied extensively in lakes, but much less attention has been paid to these movements in shallow water bodies. The refuge effect of the deeper parts of shallow water bodies might not be as important as in lakes because benthic predators in wetlands are generally very well represented (Batzer \& Ruhí, 2013). In these cases, the presence of different mesohabitats (i.e., vegetation structure) could serve as refuge for Chaoborus spp. larvae, and the existence of diel mesohabitat or horizontal migrations could be determined by the differential abundance of prey in open waters relative to vegetated areas. Overall, vertical diel migrations may be weaker than horizontal ones in shallow temporary ponds, but few studies have analysed the diel patterns of Chaoborus species in these environments (however, see Bass \& Sweet, 1984).

The present study investigates the regional distribution of chaoborids in the shallow lentic waters of the NE Iberian Peninsula and studies coexistence patterns among the different species. Due to the different adaptive strategies of Chaoborus species (e.g., different predator avoidance behaviour or adaptation to different environmental characteristics; Berendonk \& Bonsall, 2002; Kurek et al., 2010), we first intended to investigate the contribution of two main environmental factors, namely water permanence and fish predation, to their regional distribution. Second, as it is known that several Chaoborus species may be able to avoid interspecific competition (both spatially and temporally; e.g., Von Ende, 1982), we wished to examine whether there was spatial and/or temporal segregation among coexisting chaoborids. Third and finally, as diel migrations of $C$. flavicans have often been described to be mechanisms to avoid planktivorous fish (e.g., Dawidowicz et al., 1990), we intended to evaluate whether C. flavi- 
cans larvae display diel mesohabitat/horizontal migrations in two shallow, fishless ponds. Within this context, we also evaluated diel mesohabitat migrations of zooplankton and potential predators of Chaoborus spp. larvae that occurred in these ponds to identify the ultimate causes of $C$. flavicans migrations.

\section{MATERIALS AND METHODS}

\section{Sampling}

A survey comprising a total of 124 freshwater wetlands was conducted in Catalonia (NE Iberian Peninsula) haphazardly from 1993 to 2013 (Table S1, Available at www.limnetica.net/internet). All water bodies except one were shallow (i.e., $<6 \mathrm{~m}$ deep). Wetlands were classified according to their hydrology (57 wetlands were permanent and 67 were temporary) and fish presence (36 were fish-bearing and 88 were fishless). Sampling was conducted by sweeping during the day with a dip-net $22-\mathrm{cm}$ in diameter and of a $250-\mu \mathrm{m}$ mesh size (which was also used in all subsequent studies), covering all mesohabitats. Samples were preserved in situ with formaline $4 \%$ or ethanol at $70 \%$. Larvae and pupae of Chaoboridae were identified to the species level using Sæther (1972) and Balvay (1977). Because the sampling effort employed to assess the regional distribution was not the same for all of the sampling points included in the database (some samples were quantitative and some were qualitative), a presence/absence matrix ( 3 species $\times 124$ sites) was built.

In addition to the regional distribution study, three complementary field studies were carried out to describe (i) habitat and (ii) the temporal segregation among the different species, and (iii) the diel horizontal migration of $C$. flavicans.

\section{Habitat segregation study}

To describe the affinity of different species to different aquatic habitats, a study was conducted in the Can Jordà wetlands in Garrotxa Volcanic Zone Natural Park $\left(42^{\circ} 08^{\prime} 41^{\prime \prime} \mathrm{N}, 02^{\circ} 30^{\prime} 25^{\prime \prime} \mathrm{E}\right.$,
$527 \mathrm{~m}$ a.s.1.), where a group of several permanent and temporary wetlands are found in close association. In the same area (distance $<20 \mathrm{~m}$ ), we delimited a permanent and a temporary wetland that are interconnected only after extreme flooding. On 23/03/2011, when the temporary habitat had been flooded for at least one month, four 3-meter transects were performed in each habitat.

\section{Temporal segregation study}

To study the seasonal dynamics in the same pond of two different species, a study was carried out seasonally in Gorga de les Acàcies pond, in the Deveses de Salt area $\left(41^{\circ} 58^{\prime} 54^{\prime \prime} \mathrm{N}, 02^{\circ} 46^{\prime} 41^{\prime \prime} \mathrm{E}\right.$, $79 \mathrm{~m}$ a.s.l.) between November 2010 and July 2011. The pond has a single basin and a low diversity of mesohabitats, which prevented habitat segregation between the present Chaoborus species. At each sampling date, the capture methodology consisted in 20 sweeps in rapid sequence covering all mesohabitats present in the pond.

\section{Diel horizontal migration study}

To determine whether diel mesohabitat segregation occurs in very shallow ponds $(<60 \mathrm{~cm}$ depth), a field study was performed in two temporary ponds: Peça del Forn pond $\left(41^{\circ} 49^{\prime} 19^{\prime \prime} \mathrm{N}\right.$, $02^{\circ} 58^{\prime} 12^{\prime \prime} \mathrm{E}, 53 \mathrm{~m}$ a.s.l.) and Can Capçana pond $\left(41^{\circ} 52^{\prime} 11^{\prime \prime} \mathrm{N}, 02^{\circ} 53^{\prime} 42^{\prime \prime} \mathrm{E}, 133 \mathrm{~m}\right.$ a.s.l.), both in the Gavarres Area of Natural Interest. To capture Chaoboridae larvae, five 1-meter transects were performed in vegetated areas of each pond (mean depth of the transects $=37 \mathrm{~cm}$ in the Peça del Forn pond and $52 \mathrm{~cm}$ in the Can Capçana pond) and another 5 transects were performed in nonvegetated areas of each pond (mean depth of the transects $=38 \mathrm{~cm}$ and $41 \mathrm{~cm}$, respectively). Samplings were conducted in the morning $(8: 00 \mathrm{~h})$ and evening $(20: 00 \mathrm{~h})$. The sampling took place at least one month after the ponds had been filled by rain water, in October $14^{\text {th }} 2010$ (Can Capçana pond) and in October $16^{\text {th }} 2010$ (Peça del Forn pond). Diel vertical migration was not assessed in this study due to the shallowness of the ponds. 
To analyse whether the diel patterns of $C$. flavicans were due to the movements of their potential resource (i.e., zooplankton) or due to the movement of potential predators, we also evaluated the diel patterns of these two faunal groups. The abundance of potential predators of $C$. flavicans (i.e., Odonata, predatory Coleoptera and predatory Heteroptera) was estimated with the same transects used for capturing Chaoboridae. Zooplankton (i.e., Cladocera and Copepoda) were captured using 20 minnow traps per pond. Each trap was a $500 \mathrm{~mL}$ transparent plastic container (30 $\mathrm{cm}$ in length, $8 \mathrm{~cm}$ in diameter) equipped with an inverse-funnel opening, similar to those used by Beladjal et al. (1992). Ten iron bars (5 in the vegetated areas and 5 in the non-vegetated areas) were fixed to the pond bottom, and a set of two traps was attached to each iron bar. One trap was fixed at $5 \mathrm{~cm}$ below the water surface, and the other was fixed at $5 \mathrm{~cm}$ above the bottom of the pond. Traps were active during two 10-hour periods. The first period (from 10 a.m. to 8 p.m.) was used to detect the position of zooplankton during the day, and the second period (from 10 p.m. to 8 a.m.) was used to detect the position of zooplankton at night. After each 10-hour period (1 hour after dawn and dusk), the zooplankton captured in the traps were preserved in $96 \%$ ethanol and subsequently counted, measured and identified to the high-taxa level using a stereomicroscope. To study the diel patterns of zooplankton, the captures of the two traps of each iron bar were summed, thus taking into account the movement of zooplankton in all of the water column.

\section{Data analyses}

To determine whether the presence of chaoborids was independent of the regional factors analysed (water permanence and fish presence), we performed a chi-square test of independence using Chaoboridae presence/absence (all species lumped together) across the set of 124 wetlands. Because all temporary wetlands were fishless,

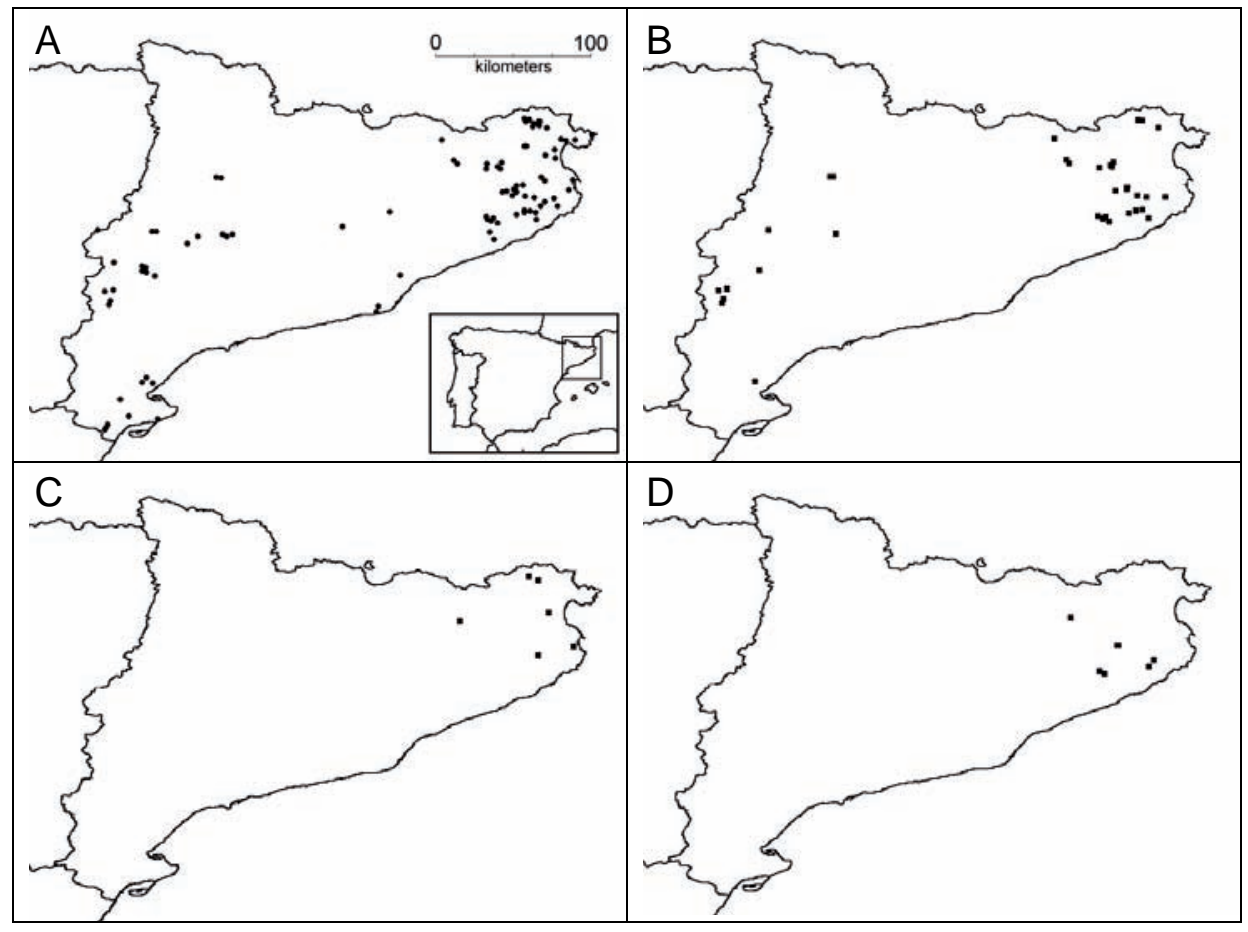

Figure 1. Map of the NE Iberian Peninsula showing the A) total sites sampled, B) sites with Chaoborus flavicans, C) sites with Chaoborus crystallinus, and D) sites with Chaoborus pallidus. Mapa del NE de la Península Ibérica mostrando la distribución de: A) localidades muestreadas; B) Chaoborus flavicans; C) Chaoborus crystallinus; D) Chaoborus pallidus. 
we performed an additional chi-square test of independence for the fish presence factor but considering only the subset of permanent wetlands. To explore the affinity to water permanence or to fish presence of each species, two additional chi-square tests of independence (one for each factor) were performed for the subset of 50 sites where the genus Chaoborus was detected. We also analysed whether Chaoborus species tended to co-occur more or less than would be expected by chance (according to the particular relative occurrences) by means of a co-occurrence null model (C-score as cooccurrence index, sequential swap algorithm, 5000 permutations).

For the first case study (habitat segregation), we tested for differences in the abundances of Chaoborus species between the two habitats (i.e., temporary and permanent) with another chi-square test of independence. For the second case study (temporal segregation), a chi-square test of independence was conducted to determine whether proportions of Chaoborus species' abundances changed across seasons. For the third case study (diel mesohabitat pattern), 3 two-way ANOVAs were conducted separately for each pond (Peça del Forn and Can Capçana ponds). The two factors were vegetation (i.e., vegetated $v s$. non-vegetated) and time (i.e., day- vs. night-time), and the abundance of $C$. flavicans, predators and zooplankton were the dependent variables, respectively. All analyses were performed using the statistical program $\mathrm{R}$ ( $\mathrm{R}$ Core Team, 2012) except for the cooccurrence null model, which was simulated in EcoSim (Entsminger, 2012).

Table 1. Occurrence and co-occurrence (\%) of the three Chaoborus species across the 50 water bodies where Chaoboridae were recorded. Ocurrencia y co-ocurrencia (\%) de las tres especies de Chaoborus de las 50 masas de agua con presencia de Chaoboridae.

\begin{tabular}{llc}
\hline Occurrence & C. crystallinus & $8 \%$ \\
alone & C. flavicans & $74 \%$ \\
& C. pallidus & $8 \%$ \\
\hline Co-ocurrence & C. crystallinus-C. flavicans & $2 \%$ \\
& C. crystallinus-C. pallidus & $0 \%$ \\
& C. flavicans-C. pallidus & $6 \%$ \\
& C. flavicans-C. pallidus-C. crystallinus & $2 \%$ \\
\hline
\end{tabular}
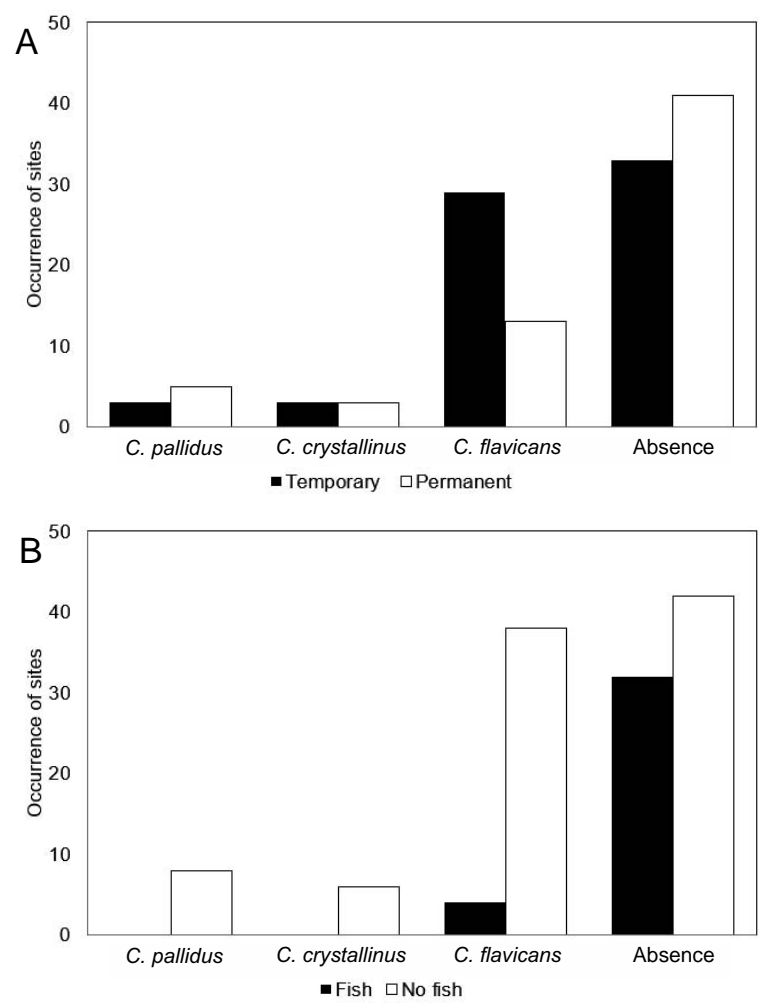

Figure 2. Bar plot showing the regional occurrences of each Chaoborus species across the two environmental factors studied: A) water permanence, and B) fish presence. Gráfico de barras mostrando las ocurrencias a nivel regional para cada especie de Chaoborus, según los dos factores ambientales estudiados: A) permanencia del agua, y B) presencia de peces.

\section{RESULTS}

\section{Distribution, co-occurrences among Chaoborus species and habitat use}

Chaoborus larvae or pupae were detected in 50 out of the 124 surveyed water bodies (see Table S1). Three species of Chaoborus were found: C. flavicans (Meigen, 1830), C. crystallinus (De Geer, 1776) and C. pallidus (Fabricius, 1781). C. flavicans was the most widespread species, being present in $84 \%$ of the water bodies where chaoborids were recorded (Fig. 1). $C$. pallidus and $C$. crystallinus were rare, being present in $16 \%$ and $12 \%$ of the wetlands, respectively (Fig. 1, Table 1). Co-occurrences among species were generally low (Table 1) but not significantly different from what would be 
expected by chance (observed C-index $=0.283$; simulated C-index by the null model $=0.290$; $\left.P_{\text {(obs } \leq \text { expected })}=0.62 ; P_{(\text {obs } \geq \text { expected })}=1\right)$. The species pair that co-occurred most often was $C$. flavicans-C. pallidus (6\%). C. crystallinus- $C$. flavicans showed low values of co-occurrence (2\%) and we did not observe any co-occurrence between $C$. crystallinus and $C$. pallidus. The three species (i.e., C. flavicans-C. pallidus- $C$. crystallinus) co-occurred in only a single water body $(2 \%)$.

The analysis of habitat use at the regional scale (Fig. 2) showed that the presence of Chaoboridae (regardless of the species identity) was dependent on both water permanence $\left(\chi_{1}^{2}=5.67 ; p=0.017\right)$ and fish presence, if we considered either only permanent wetlands $\left(\chi_{1}^{2}=11.73 ; p<0.001\right)$ or all wetlands together $\left(\chi_{1}^{2}=16.32 ; p<0.001\right)$. The proportions of the different species (considering only sites where Chaoborus spp. was present) were independent of water permanence $\left(\chi_{2}^{2}=3.30 ; p=0.192\right)$ and fish presence $\left(\chi_{2}^{2}=1.43 ; p=0.488\right)$, implying that the pattern was species-consistent (i.e., all species occurred mainly in temporary or permanent but fishless wetlands).

\section{Habitat segregation}

Estany Vell de Can Jordà was the only site that recorded all 3 Chaoborus species co-occurring. The abundances among Chaoborus species were significantly different between habitat type $\left(\chi_{2}^{2}=100.46 ; p<0.0001\right)$ (Fig. 3). Chaoborus flavicans was dominant in the temporary wetland (89.7\%), whereas C. pallidus was the most abundant species in the permanent wetland $(73.8 \%)$. C. crystallinus was rare $(<3 \%)$ in both habitats.

\section{Temporal segregation}

Two species were present in the Gorga de les Acàcies pond: C. flavicans and C. pallidus. The temporal analysis (Fig. 4) showed a different proportion of the species abundances seasonally $\left(\chi_{3}^{2}=113.73 ; p<0.001\right)$, with $C$. pallidus being more abundant in winter and $C$. flavicans dominating in autumn and spring.

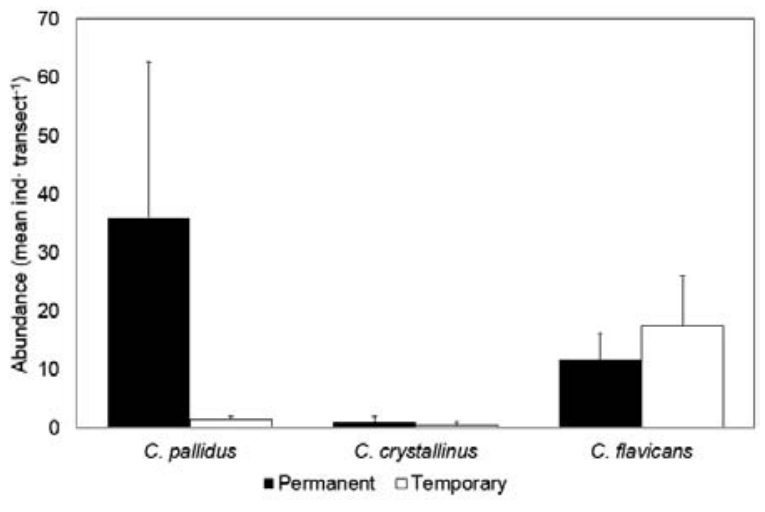

Figure 3. Bar plot of the habitat segregation study in Can Jordà wetlands, showing mean abundances and standard deviation of the three recorded species of Chaoborus in the two habitats studied. Gráfico de barras de la segregación de hábitat en los humedales de Can Jordà, mostrando las abundancias y las desviaciones estándar de las tres especies de Chaoborus en los dos hábitats analizados.

\section{Diel horizontal migration}

The diel mesohabitat analysis was performed to compare the abundances of $C$. flavicans, their potential predators and their potential resource (i.e., zooplankton) in vegetated $v s$. non-vegetated zones and during day- vs. night-time. For the Peça del Forn pond, the abundances of $C$. flavicans and those of predators were significantly higher in the vegetated area than the non-vegetated area $\left(F_{1,16}=5.36, \quad p=0.034\right.$;

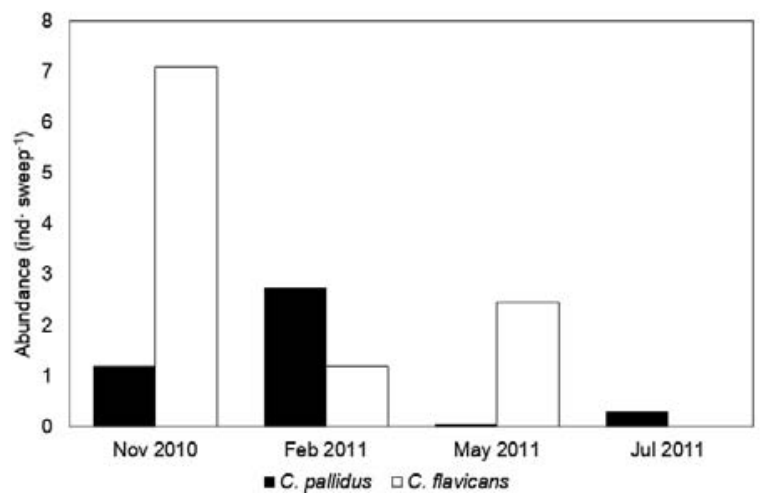

Figure 4. Bar plot of the temporal segregation study in the Gorga de les Acàcies pond, showing the abundances of the two recorded species of Chaoborus from November 2010 to July 2011. Gráfico de barras de la segregación temporal en la charca de la Gorga de les Acàcies, mostrando las abundancias de dos especies de Chaoborus desde Noviembre de 2010 a Julio de 2011. 
$F_{1,16}=25.92, p<0.001$, respectively), but no significant differences were found between day- and night-time $\left(F_{1,16}=0.07, p=0.799\right.$; $F_{1,16}=1.10, p=0.309$, respectively). Additionally, the interaction between both factors was not significant either $\left(F_{1,16}=1.21, p=0.286\right.$; $F_{1,16}=1.96, p=0.181$, respectively). In contrast, the relative abundance of zooplankton was significantly higher during day-time than night-time $\left(F_{1,16}=16.30, p<0.001\right)$, but no significant differences were found between vegetated and non-vegetated zones or in the interaction between both factors $\left(F_{1,16}=3.40\right.$, $p=0.084 ; \quad F_{1,16}=0.07, \quad p=0.801$, respectively). In the Can Capçana pond, there was a significant distribution of predators according to both factors $\left(F_{1,16}=49.61, p<0.001\right.$ for time, and $F_{1,16}=6.98, p=0.018$ for vegetation), indicating that more predators occurred during night-time and in vegetated areas than during day-time and in non-vegetated areas. Zooplankton abundances were not influenced by vegetation $\left(F_{1,16}=2.12, \quad p=0.165\right)$ but were higher during day-time than night-time $\left(F_{1,16}=19.31, p<0.001\right)$. Moreover, the interaction between both factors was not significant $\left(F_{1,16}=2.08, p=0.168\right)$. Finally, there were no significant differences in the abundances of $C$. flavicans between vegetated and non-vegetated zones $\left(F_{1,16}=2.51, p=0.133\right)$ or between dayand night-time $\left(F_{1,16}=0.26, p=0.615\right)$, with the factor interaction not being significant either $\left(F_{1,16}=1.15, p=0.300\right)$.

\section{DISCUSSION}

This study detected all 3 Chaoboridae species that had been previously recorded in the Iberian Peninsula (Carles-Tolrá, 2002; Boix et al., 2005): C. flavicans, C. crystallinus and C. pallidus. Furthermore, knowledge on the distribution of $C$. pallidus, only known from the Gavarres mountain range so far (Boix et al., 2005), was extended to eight distinct populations.

All species were detected in both permanent and temporary wetlands. C. flavicans clearly dominated at the regional scale independent of wetland type, whereas the other two species were rarer. $C$. flavicans is a wide-spread species inhabiting all types of lentic environments, from shallow temporary ponds to lakes or dams (e.g., Miracle, 1976; Prat, 1980; Boix \& Sala, 2002). However, in our study (focused on shallow wetlands), we found that C. flavicans was associated with temporary wetlands and fishless permanent ponds. It is known that $C$. flavicans is able to live in both fish-bearing and fishless water bodies (Berendonk, 1999; Garcia \& Mittelbach, 2008), but the predation pressure of some fish species on $C$. flavicans can be important (Margaritora et al., 2001; Regmi et al., 2013). On the contrary, C. crystallinus and C. pallidus appeared in temporary or fishless permanent ponds. Both species had already been recorded in small ponds (Seminara \& Bazzanti, 1984; Berendonk $\&$ Bonsall, 2002), and at least in the case of $C$. crystallinus, they are known to avoid oviposition in fish-bearing waters (Berendonk, 1999). However, the regional dominance of $C$. flavicans could not only be explained by the presence of fish as all species occurred mainly in fishless wetlands. Berendonk and Bonsall (2002) also found a clear local dominance of C. flavicans over $C$. crystallinus, due to the distinct lifestyle strategies found among Chaoborus spp. larvae. These authors found that $C$. flavicans lives in lakes (where it can develop large populations) and ponds, creating a population structure that consists of a series of small habitat patches within the range of a large habitat patch (i.e., a mainland-island metapopulation structure; Berendonk \& Bonsall, 2002). In contrast, despite their relatively higher dispersal capacity, C. crystallinus presents higher risks of local extinction due to its different metapopulation structure, namely a large network of similar small patches (usually small fishless ponds; Berendonk \& Bonsall, 2002). Another factor that could contribute to its relatively higher risk of local extinction is the decreasing number of fishless waters, due to increasing exotic fish introductions (e.g., Leyse et al., 2004; Catalan et al., 2006). Furthermore, the low concentration (or absence) of UV-absorbing compounds in C. crystallinus and C. pallidus (Nagiller \& Sommaruga, 2009) 
could also contribute to explaining the observed preference of these species for ponds that are shaded by canopy and/or macrophytes.

From our regional survey we concluded that the observed co-occurrences $(10 \%)$ were neither more nor less frequent than should be expected by random draws from the Chaoboridae regional pool. Nevertheless, in the field studies we detected spatial and temporal segregation patterns among Chaoborus species that showed a partial overlap. For instance, in the habitat segregation study, we found that the temporary wetland was dominated by $C$. flavicans and that the permanent wetland was dominated by $C$. pallidus. Similarly, in the temporal field study, we observed that the relative abundances of both $C$. flavicans and C. pallidus changed over time. In North America, it has been observed that the segregation of Chaoborus species may be caused by competitive exclusion or by intraguild predation. In that case, C. punctipennis (Say, 1823) is known to be eliminated by $C$. americanus (Johannsen, 1903) in fishless bog lakes due to the early phenology and large size of $C$. americanus (Von Ende, 1979). C. punctipennis may also co-occur with $C$. flavicans, but their different phenologies allow for different larval size, hence reducing interspecific competition for prey (Von Ende, 1982).

It is widely known that Chaoborus larvae perform diel vertical migrations in several aquatic environments, including temporary ponds (e.g., Bass \& Sweet, 1984; Meerhoff et al., 2007; Lagergren et al., 2008). The existence of diel horizontal migrations has also been reported in Chaoborus spp. larvae, but these have usually been associated with incomplete vertical migrations (Voss \& Mumm, 1999) or during food shortages (at a seasonal scale; LiljendahlNurminen et al., 2002). In our study, C. flavicans did not display, overall, a diel horizontal migration. However, in one of the ponds (Peça del Forn pond), C. flavicans was more abundant in vegetated than in non-vegetated areas during both day- and night-time. Its horizontal distribution was not explained by any mesohabitat migration of zooplankton but coincided with the distribution of its potential predators (anisopteran odonates were the most abundant predator in this pond). Although Chaoborus spp. larvae typically inhabit open waters (Sæther, 1972) they are sometimes associated with other mesohabitats, such as emergent or floating-leaved plants (Smiley \& Tessier, 1998; Iglesias et al., 2007), where they can avoid visual predators (Folsom \& Collins, 1984; Burks et al., 2001). It is well known that aquatic vegetation influences the structure of macroinvertebrate communities, not only by providing food resources (e.g., Burdett \& Watts, 2009) but also by offering physical refuge from predation (e.g., Hampton \& Duggan, 2003; Paukert \& Willis, 2003; Gascón et al., 2013). Although we cannot rule out the possibility that chaoborids were performing diel vertical migration using sediment as a refuge, as has been documented (Bass \& Sweet, 1984; Gosselin \& Hare, 2003), our study suggests that in shallow water bodies, vegetation structure may play an important role as a refuge for chaoborid larvae.

\section{ACKNOWLEDGEMENTS}

We thank the Garrotxa Volcanic Zone Natural Park, the Consorci de les Gavarres, and the technical staff of the Salt municipality for permissions to perform our study in the ponds under their management. We also thank Jordi Compte, Helena Dehesa, Jaume Gifre, and Eli Montserrat, for field and laboratory assistance. This work was supported by the "Ministerio de Ciencia e Innovación" (CGL2011-23907) and the Generalitat de Catalunya (ref. 2014 SGR 484).

\section{REFERENCES}

ABELLÁN, P., D. SÁNCHEZ-FERNÁNDEZ, A. MILLÁN, F. BOTELLA, J. A. SÁNCHEZ-ZAPATA \& A. GIMÉNEZ. 2006. Irrigation pools as macroinvertebrate habitat in a semi-arid agricultural landscape (SE Spain). Journal of Arid Environments, 67: 255-269.

ALARCÓN-ELBAL, P. M., A. CASANOVA, I. RUIZ-ARRONDO, S. DELACOUR, R. PINAL, D. BOIX, J. SALA \& J. LUCIENTES. 2011. Primera cita de Chaoborus crystallinus (De Geer, 1776) (Diptera: Chaoboridae) para la provincia 
de Zaragoza (noreste de España). Boletín de la Sociedad Entomológica Aragonesa, 48: 466-468.

BALVAY, G. 1977. Détermination des larves de Chaoborus (Diptera, Chaoboridae) rencontrées en France. Annales d'Hydrobiologie, 8: 27-32.

BASS, D. \& M. SWEET. 1984. Do Chaoborus larvae migrate in temporary pools? Hydrobiologia, 108: 181-185.

BATZER, D. P. \& A. RUHÍ. 2013. Is there a core set of organisms that structure macroinvertebrate assemblages in freshwater wetlands? Freshwater Biology, 58: 1647-1659.

BELADJAL, L., J. MERTENS \& H. J. DUMONT. 1992. A simple basket trap for estimating relative abundances of some components of hyporheic faunas: application to the Cladocera. Stygologia, 7: 193-195.

BERENDONK, T. U. 1999. Influence of fish kairomones on the ovipositing behavior of Chaoborus imagines. Limnology and Oceanography, 44: 454458.

BERENDONK, T. U. 2002. Distribution and ecology of phantom midge larvae in Southern France and Italy (Diptera: Chaoboridae). Studia dipterologica, 9: 109-112.

BERENDONK, T. U. \& M. B. BONSALL. 2002. The phantom midge and a comparison of metapopulation structures. Ecology, 83: 116-128.

BOIX, D., S. GASCÓN, M. MARTINOY, E. MONTSERRAT \& J. SALA. 2005. Fauna aquàtica de les Gavarres. Consorci de les Gavarres. Monells.

BOIX, D. \& J. SALA. 2002. Riqueza y rareza de los insectos acuáticos de la laguna temporal de Espolla (Pla de l'Estany, Cataluña). Boletín de la Asociación Española de Entomología, 26: 45-57.

BORKENT, A. 1979. Systematics and bionomics of the species of the subgenus Schadonophasma Dyar and Shannon (Chaoborus, Chaoboridae, Diptera). Quaestiones Entomologicae, 15: 122-255.

BORKENT, A. 1993. A world catalogue of fossil and extant Corethrellidae and Chaoboridae (Diptera), with a listing of references to keys, bionomic information and descriptions of each known life stage. Entomologica Scandinavica, 24: 1-24.

BURDETT, A. S. \& R. J. WATTS. 2009. Modifying living space: an experimental study of the influences of vegetation on aquatic invertebrate community structure. Hydrobiologia, 618: 161-173.

BURKS, R. L., E. JEPPESEN \& D. M. LODGE. 2001. Pelagic prey and benthic predators: impact of odonate predation on Daphnia. Journal of the
North American Benthological Society, 20 (4): 615-628.

CARLES-TOLRÁ, M. 2002. Catálogo de los Diptera de España, Portugal y Andorra (Insecta). Monografías SEA, 8. Sociedad Entomológica Aragonesa. Zaragoza.

CARLES-TOLRÁ, M. \& M. SALOÑA. 2004. Dípteros nocturnos y crepusculares (Insecta: Diptera) capturados con trampas Malaise y trampas de luz en la provincia de Vizcaya (Bizkaia, España). Heteropterus Revista de Entomología, 4: 41-49.

CATALAN, J., L. CAMARERO, M. FELIP, S. PLA, M. VENTURA, T. BUCHACA, F. BARTUMEUS, G. DE MENDOZA, A. MIRÓ, E. O. CASAMAYOR, J. M. MEDINA-SÁNCHEZ, M. BACARDIT, M. ALTUNA, M. BARTRONS \& D. DÍAZ DE QUIJANO. 2006. High mountain lakes: extreme habitats and witnesses of environmental changes. Limnetica, 25: 551-584.

DAWIDOWICZ, P., J. PIJANOWSKA \& K. CIECHOMSKI. 1990. Vertical migration of Chaoborus larvae is induced by the presence of fish. Limnology and Oceanography, 35: 1631-1637.

ENTSMINGER, G. L. 2012. EcoSim Professional: Null modeling software for ecologists, Version 1. Acquired Intelligence Inc., Kesey-Bear, \& Pinyon Publishing, Montrose. http://www.garyentsminger. com/ecosim/index.htm

FLORENCIO, M., L. SERRANO, C. GÓMEZ-RODRÍGUEZ, A. MILLÁN \& C. DÍAZ-PANIAGUA. 2009. Inter- and intra-annual variations of macroinvertebrate assemblages are related to the hydroperiod in Mediterranean temporary ponds. Hydrobiologia, 634: 167-183.

FOLSOM, T. C. \& N. C. COLLINS. 1984. The diet and foraging behavior of the larval dragonfly Anax junius (Aeshnidae), with an assessment of the role of refuges and prey activity. Oikos, 42: 105-113.

GARCÍA, E. A. \& G. G. MITTELBACH. 2008. Regional coexistence and local dominance in Chaoborus: species sorting along a predation gradient. Ecology, 89: 1703-1713.

GASCÓN, S., X. LLOPART, A. RUIZ-NAVARRO, J. COMPTE, D. VERDIELL-CUBEDO, D. BOIX, F. J. OLIVA-PATERNA, X. D. QUINTANA \& M. TORRALVA. 2013. The effects of Aphanius iberus predation on an aquatic community: diel changes and the role of vegetation. Fundamental and Applied Limnology, 182: 75-87. 
GERALDES, A. M. \& M. J. BOAVIDA. 2004. Do littoral macrophytes influence crustacean zooplankton distribution? Limnetica, 23: 57-64.

GOSSELIN, A. \& L. HARE. 2003. Burrowing behavior of Chaoborus flavicans larvae and its ecological significance. Journal of the North American Benthological Society, 22: 575-581.

HAMPTON, S. E. \& I. C. DUGGAN. 2003. Diel habitat shifts of macrofauna in a fishless pond. Marine and Freshwater Research, 54: 797-805.

IGLESIAS, C., G. GOYENOLA, N. MAZZEO, M. MEERHOFF, E. RODÓ \& E. JEPPESEN. 2007. Horizontal dynamics of zooplankton in subtropical Lake Blanca (Uruguay) hosting multiple zooplankton predators and aquatic plant refuges. $\mathrm{Hy}$ drobiologia, 584: 179-189.

KUREK, J., L. CWYNAR, R. WEEBER, D. JEFFRIES \& J. SMOL. 2010. Ecological distributions of Chaoborus species in small, shallow lakes from the Canadian Boreal Shield ecozone. Hydrobiologia, 652: 207-221.

LAGERGREN, R., K. LEBERFINGER \& J. A. E. STENSON. 2008. Seasonal and ontogenetic variation in diel vertical migration of Chaoborus flavicans and its effect on depth-selection behavior of other zooplankton. Limnology and Oceanography, 53: 1083-1092.

LAMONTAGNE, S., D. B. DONALD \& D. W. SCHINDLER. 1994. The distribution of four Chaoborus species (Diptera: Chaoboridae) along an elevation gradient in Canadian Rocky Mountain lakes. Canadian Journal of Zoology, 72: 1531-1537.

LEYSE, K. E., S. P. LAWLER \& T. STRANGE. 2004. Effects of an alien fish, Gambusia affinis, on an endemic California fairy shrimp, Linderiella occidentalis: implications for conservation of diversity in fishless waters. Biological Conservation, 118: 57-65.

LILJENDAHL-NURMINEN, A., J. HORPPILA, P. ELORANTA, T. MALINEN \& L. UUSITALO. 2002. The seasonal dynamics and distribution of Chaoborus flavicans larvae in adjacent lake basins of different morphometry and degree of eutrophication. Freshwater Biology, 47: 1283-1295.

MARGARITORA, F. G., O. FERRARA \& D. VAGAGGINI. 2001. Predatory impact of the mosquitofish (Gambusia holbrooki Girard) on zooplanktonic populations in a pond at Tenuta di Castelporziano (Rome, Central Italy). Journal of Limnology, 60: 189-193.
MARTÍNEZ-SANZ, C., C. S. S. CENZANO, M. FERNÁNDEZ-ALÁEZ \& F. GARCÍA-CRIADO. 2012. Relative contribution of small mountain ponds to regional richness of littoral macroinvertebrates and the implications for conservation. Aquatic Conservation: Marine and Freshwater Ecosystems, 22: 155-164.

MEERHOFF, M., C. IGLESIAS, F. T. DE MELLO, J. M. CLEMENTE, E. JENSEN, T. L. LAURIDSEN \& E. JEPPESEN. 2007. Effects of habitat complexity on community structure and predator avoidance behaviour of littoral zooplankton in temperate versus subtropical shallow lakes. Freshwater Biology, 52: 1009-1021.

MIRACLE, M. R. 1976. Distribución en el espacio $y$ en el tiempo de las especies del zooplancton del lago de Banyoles. Monografías, 5. Ministerio de Agricultura, Instituto Nacional para la Conservación de la Naturaleza, Madrid.

NAGILLER, K. \& R. SOMMARUGA. 2009. Differential tolerance of UV radiation between Chaoborus species and role of photoprotective compounds. Journal of Plankton Research, 31: 503-513.

PAUKERT, C. P. \& D. W. WILLIS. 2003. Aquatic invertebrate assemblages in shallow prairie lakes: fish and environmental influences. Journal of Freshwater Ecology, 18: 523-536.

PERSAUD, A. D. \& P. J. DILLON. 2010. Ontogenetic differences in isotopic signatures and crop contents of Chaoborus. Journal of Plankton Research, 32: 57-67.

PRAT, N. 1980. Bentos de los embalses españoles. Oecologia Aquatica, 4: 3-43.

R CORE TEAM. 2012. R: A language and environment for statistical computing. R Foundation for Statistical Computing, Vienna. http://www.R-pro ject.org

REGMI, B. P., J. S. WIVEGH \& A. HOBÆK. 2013. Population decline and life-cycle changes in a phantom midge (Chaoborus flavicans) after introduction of planktivorous fish. Freshwater Biology, 58: 1436-1446.

SÆTHER, O. A. 1972. Chaoboridae. In: Die Binnengewässer, 26: Das Zooplankton der Binnengewässer, 1. Teil. J. Elster \& W. Ohle (eds.): 257280. E. Schweizerbart'sche Verlagsbuchhandlung, Stuttgart.

SEMINARA, M. \& M. BAZZANTI. 1984. Distribution of Chaoborus (Diptera, Chaoboridae) in lenthic waters of Latium (Central Italy) with 
remarks on its occurrence in Italy. Rivista di Idrobiologia, 23: 115-127.

SMILEY, E. A. \& A. J. TESSIER. 1998. Environmental gradients and the horizontal distribution of microcrustaceans in lakes. Freshwater Biology, 39: 397-409.

STAHL, J. B. 1966. The ecology of Chaoborus in Myers Lake, Indiana. Limnology and Oceanography, 11: 177-183.

TJOSSEM, S. F. 1990. Effects of fish chemical cues on vertical migration behavior of Chaoborus. Limnology and Oceanography, 35: 1456-1468.

TRIGAL, C., F. GARCÍA-CRIADO \& C. FERNÁNDEZ-ALÁEZ. 2007. Macroinvertebrate communities of mediterranean ponds (North Iberian Plateau): importance of natural and human-induced variability. Freshwater Biology, 52: 2042-2055.

VON ENDE, C. N. 1979. Fish predation, interspecific predation, and the distribution of two Chaoborus species. Ecology, 60: 119-128.

VON ENDE, C. N. 1982. Phenology of four Chaoborus species. Environmental Entomology, 11: 917.

VOSS, S. \& H. MUMM. 1999. Where to stay by night and day: Size-specific and seasonal differences in horizontal and vertical distribution of Chaoborus flavicans larvae. Freshwater Biology, 42: 201-213.

WAGNER, R., M. BARTÁK, A. BORKENT, G. COURTNEY, B. GODDEERIS, J.-P. HAENNI, L. KNUTSON, A. PONT, G. E. ROTHERAY, R. ROZKOŠNÝ, B. SINCLAIR, N. WOODLEY, T. ZATWARNICKI \& P. ZWICK. 2008. Global diversity of dipteran families (Insecta Diptera) in freshwater (excluding Simulidae, Culicidae, Chironomidae, Tipulidae and Tabanidae). Hydrobiologia, 595: 489-519. 